\title{
Cross Sectional Study Regarding the Association Between Sweetened Beverages Intake, Fast-food Products, Body Mass Index, Fasting Blood Glucose and Blood Pressure in the Young Adults from North-western Romania
}

\author{
AMORIN REMUS POPA ${ }^{1,2}$, COSMIN MIHAI VESA $^{1,2 *}$, DIANA UIVAROSAN ${ }^{1}$, CLAUDIA MARIA J URCA $^{1}$, GHEORGHITA ISVORANU ${ }^{3}$, \\ BOGDAN SOCEA ${ }^{4,5}$, ANA MARIA ALEXANDRA STANESCU ${ }^{4}$, MIHAELA ADELA IANCU ${ }^{4}$, IOAN SCARNECIU ${ }^{6}$, DANA CARMEN ZAHA ${ }^{1,2}$ \\ IUniversity of Oradea, Faculty of Medicine and Pharmacy, 101 Decembrie Sq., 410073, Oradea, Romania. \\ ${ }^{2}$ Clinical County Emergency Hospital of Oradea, 65 Gh. Doja, 410169, Oradea, Romania \\ 3Victor Babes National Institute of Pathology, 99-101 Splaiul Independentei, 050096, Bucharest, Romania \\ ¿University of Medicine and Pharmacy Carol Davila, 8 Eroii Sanitari Str., 050474, Bucharest, Romania \\ ${ }^{5}$ St. Pantelimon Clinical Emergency Hospital, 340-342 Pantelimon Str, 021659, Bucharest, Romania \\ ${ }^{6}$ Transilvania University of Medicine and Pharmacy, 56 Nicolae Balcescu Str., 500019, Brasov, Romania
}

The study investigated the association between the frequency of sweetened beverages intake and body mass index, diet choices, hypertension, and glycaemia in 1158 individuals from north western Romania, aged between 20 and 39 years. We found a high prevalence (87.48\%) of soda consumption. There was a linear correlation between the number of sweetened beverages servings/week and unhealthy lifestyle expressed as frequency of fast-food consumption. A significant statistical association was found between soda consumption and prevalence of high blood pressure and impaired fasting glycaemia. Individuals who did not consumed sweetened beverages, had a prevalence of impaired fasting glucose and hypertension of $6 \%$ and respectively 13\%; those who consumed more than 8 servings/week had a prevalence of impaired fasting glucose and hypertension of 19\%. Inappropriate nutrition (lack of fruits and vegetables in food, consumption of fats and processed sugars or added sugars beverages) have increased the incidence of chronic diseases. We consider that public health policies regarding soda consumption are required.

Keywords: sweetened beverages intake, fast-food, body mass index, blood glucose, blood pressure

The proportion of obese and overweight individuals has increased dramatically in the last two decades. It is estimated that in 2030 the total number of overweight individuals will represent $38 \%$ of the world population and the obese individuals will represent $20 \%$ of the world population [1]. A possible cause of this epidemic is the increase of total calories intake, mainly because of the increase of carbohydrates consumption, as added sugars. It is estimated that in the United States of America 15.8\% of the total caloric intake comes from added sugars and $47 \%$ of these added sugars comes from sweetened beverages [2].

The effects of the increased soda intake, on the body mass index have been demonstrated in numerous studies, for example in the Framingham Offspring study consuming of $\geq 1$ soda drink/day was associated with a prevalence of obesity higher with 37\% than in individuals who consumed $<1$ soda drink/day [3].

In European population, in a prospective study done in Spain, which included 7000 participants, the increased soda consumption was associated with $3 \mathrm{~kg}$ or more increasing in weight, after an average follow-up period of 28.5 months. Soda consumption is associated with numerous health risks, being demonstrated that it increases the risk of developing type 2 diabetes [4], and cardiovascular diseases [5-7]. Another observation is that the increased intake of sodas is not associated with a compensatory decreased intake of high caloric solid foods. It was revealed that consuming a large ammount of sweetened beverages was associated with increased intake of snacks and high fat foods [8], therefore individuals tend to be grouped in unhealthy or healthy eating patterns.

In our study, we tried to identify the prevalence and frequency of soda consumption (only the sweetened beverages with added sugars) in the individuals aged between 20-39 years, from north-western Romania, and the association between the frequency of sweetened beverages intake and fast-food intake, fasting glycaemia, and systolic/ diastolic blood pressure. It is the first regional study that approaches the issue of the impact of added sugar beverages consumption on nutritional status and prevalence of metabolic abnormalities, such as impaired fasting glycaemia or high blood pressure, in the young population from north-western Romania.

\section{Experimental part}

The study is a cross-sectional one that had the objective to assess the impact of added sugars intake from sweetened beverages on the body-mass index and on the frequency of impaired fasting glucose and high systolic and diastolic blood pressure of the young adults from northwestern Romania. Also, we investigated the possible association between the frequency of soda consumption and the frequency of fast-food products consumption in this age group.

The research was conducted respecting the WMA Declaration of Ethical Helsinki - Medical Research Involving Human Principles for Subjects; it was also approved by the Ethics Commission of the Council of Medicine and Pharmacy Faculty, University of Oradea, Oradea, 
Romania. All patients gave their written consent for the participation in the study, and all 20 general practitioners approved the selection of the individuals from their patientslists for the inclusion in this study.

We included individuals from 20 clinics of general practitioners, from 5 urban and 5 rural locations from Bihor County, north-western Romania, aged between 20 and 39 years old, corresponding to young adulthood stage of human development. The study was done between J anuary and October 2018.

Inclusion criteria of the patients were: individuals with ages between 20 and 38 years and the agreement for the participation in the study. Exclusion criteria were: individuals with metabolic diseases or other chronic diseases that could influence the body weight (hypothyroidism, hyperthyroidism, Cushing disease, neoplasia, Crohn disease, ulcerative colitis etc.), individuals diagnosed with diabetes mellitus, individuals with known hypertension. We included 1200 individuals, 60 individuals from every clinic. Patients were randomly selected in order to ensure the representativeness of the included population. 42 of them failed to present for the measurement of blood pressure and fasting glycaemia determination and were excluded from the study. 1158 individuals completed the study.

At the first visit, we assessed the frequency of consumption of sweetened beverages/ week over the past year, only the beverages that contained added sugars (glucose or fructose syrup). The consumption of diet soda or beverages (like fruit juices) were excluded from the study, and it was defined the serving of a sweetened beverage as the intake of $500 \mathrm{~mL}$ of soda. Also, we determined the frequency of fast-food consumption/week over the past year. Fast-food consumption/week was assessed by giving the patient a list that included foods labeled as fast-foods (hamburgers, fried potatoes, doughnuts, pizza, crispy strips etc.) in order to make the notion clear for the study participants. Body mass index was calculated with the classical equation:

\section{$B M I=$ weight $(\mathrm{kg}) /[\text { height }(\mathrm{m})]^{2}$}

During the first visit of the patient, the systolic blood pressure, diastolic blood pressure, and fasting glycaemia were determined. Blood pressure was measured with the classical Korotkoff method. Glycaemia was determined in the morning, during the 8.00 a.m. -9 a.m. interval, after a period of minimum 8 hours of fasting. Venous blood was collected in order to obtain an accurate value of serum blood glucose. Patients with abnormal values of fasting blood glycaemia and blood pressure were asked to come to a second visit, one week later, when the determination of blood pressure and fasting glycaemia were repeated by the same methods, and a diagnosis of impaired fasting glucose or hypertension was established. Collected data was analyzed using Microsoft Excel Software version 2016.

\section{Results and discussions}

There were 574 men and 584 women included in the study. The mean age of the included patients was $30.7 \pm 8.5$ years old. Mean body mass index was $23.5 \mathrm{~kg} / \mathrm{m}^{2}$ (table 1 ). Prevalence of overweight was $15.7 \%$ and obesity of $5.8 \%$. The prevalence of sweetened beverages consumption was $87.48 \% .12 .52 \%$ of the included individuals declared that they did not consume any sweetened beverage/week. In table 1 it can be observed that $29.97 \%$ of persons consume 3-4 servings of sweetened beverages/week.

Table 1

CHARACTERISTICS OF THE INCLUDED PERSONS

\begin{tabular}{|c|c|}
\hline Variable & $\begin{array}{c}\text { Values } \\
\text { (mean, standard deviation) }\end{array}$ \\
\hline Age & $30.7 \pm 8.5$ years \\
\hline Sex (men) & $49.56 \%$ \\
\hline Environment (urban) & $50.43 \%$ \\
\hline Body-mass index & $23.5 \pm 5.8 \mathrm{~kg} / \mathrm{m}^{2}$ \\
\hline Servings of soda/week & $3.7 \pm 2.8$ \\
\hline Times buying fast-food/week & $2.1 \pm 1.5$ \\
\hline Glycaemia & $87.5 \pm 6.5 \mathrm{mg} / \mathrm{dL}$ \\
\hline Systolic blood pressure & $139 \pm 13.7 \mathrm{~mm} \mathrm{Hg}$ \\
\hline Diastolic blood pressure & $82 \pm 5.8 \mathrm{mmHg}$ \\
\hline
\end{tabular}

We found a statistically significant correlation, $p<0.01$, between the frequency of soda consumption/week and body mass index, individuals that did not consume any sweetened beverage/week had an average of BMI of 21.8 $\mathrm{kg} / \mathrm{m}^{2}$, while individuals that consumed $>8$ servings/week had an average BMI of $25.6 \mathrm{~kg} / \mathrm{m}^{2}$. The high consumption of sweetened beverages/week was associated with a high consumption of fast-foods/week. Individuals that did not consume any soda/week bought on average fast-food products 1.5 times/week, while individuals that consumed $>8$ servings of soda/week bought on average fast-food products 4.5 times/week.

Figure 1 presents the relationship between number of soda servings/week and body mass index, and figure 2 depicts the relationship between the number of soda servings/week and the number of times of buying fast food products/week.

After calculating the mean values of fasting blood glucose, systolic blood pressure and diastolic blood pressure in each group of soda drinking frequency, we observed that there was a statistically significant correlation between the number of servings of sweetened beverages/week and the value of fasting blood glucose. The values of systolic blood pressure and diastolic blood pressure were correlated with the number of servings of soda in a week using simple linear regression, a statistically significant result was obtained $(p<0.05)$.

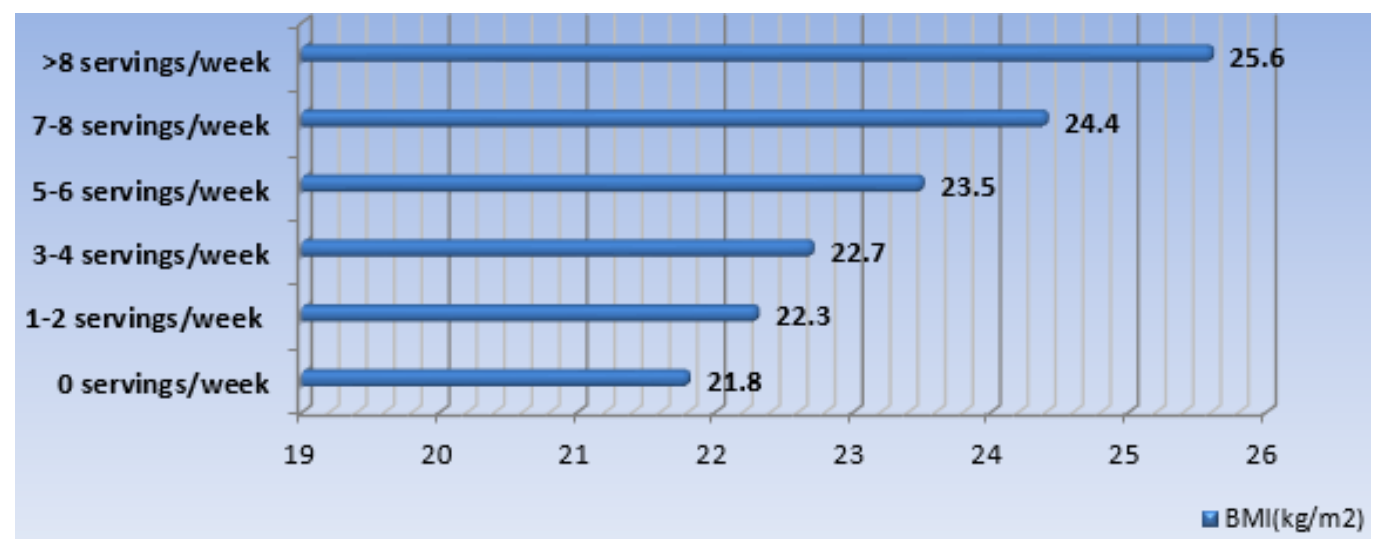

Fig. 1. Relationship between number of soda servings/ week and body mass index 


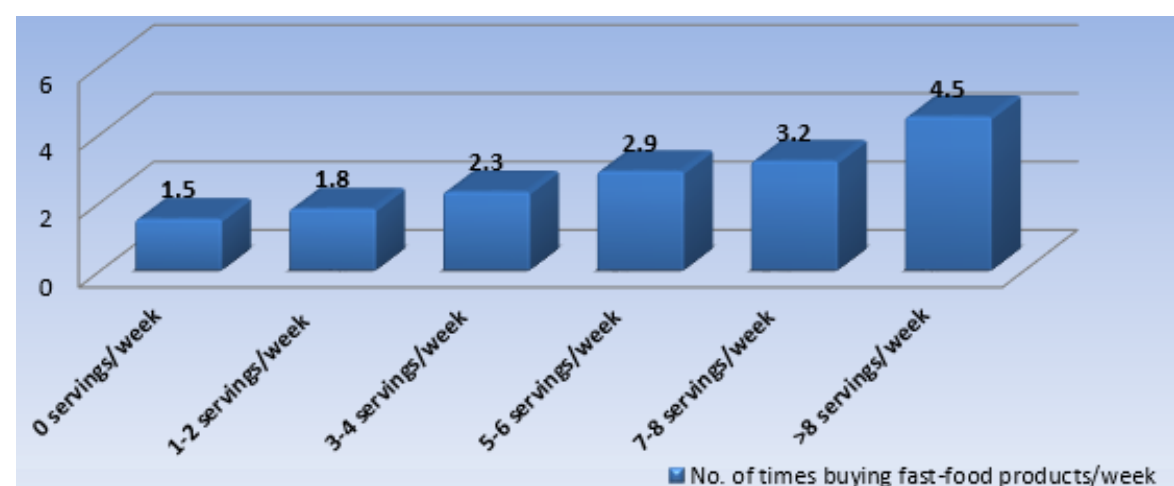

Fig. 2. Relationship between number of soda servings/week and number of times of buying fast food products/week

We determined the percentage of persons in each group that had a value of fasting blood glucose $\geq 100 \mathrm{mg} / \mathrm{dL}$. Values of fasting blood glycaemia above this limit represent the presence of impaired fasting glucose. Note that, in order to confirm the diagnosis of impaired fasting glucose, the values should be retested. We have done retesting for an accurate diagnosis. In our study, impaired fasting glucose frequency was significantly higher in groups with higher intake of soda. The percentage of persons with systolic blood pressure $>140 \mathrm{~mm} \mathrm{Hg}$ or diastolic blood pressure $>90 \mathrm{~mm} \mathrm{Hg}$ was also significantly higher in groups with higher intake of soda consumption (table 2).

Our study confirms the relationship between soda intake and body mass index. This association has been also investigated in numerous studies. Table 3 presents the association between the intake of soda, fasting blood glucose, systolic and diastolic blood pressure

A study that investigated the impact of sweetened beverages consumption on overweight and obesity concluded that $1 \%$ increase in soda consumption lead to an additional of 4.8 individuals in 100 to be obese [ 9 ]. Also, the same study estimated that the frequency of soda consumption will increase in the next 5 years, starting from 2013 [9].

A meta-analysis demonstrated that increased soda consumption is responsible for an increased energy intake, is associated with a poor diet and medical problems such as high blood pressure and diabetes [10]. Individuals who consume more sweetened beverages tend to have diets that are unhealthy. It was demonstrated that soda consumption was associated with a lower calcium intake, lower intake of fruits and vegetables, and a reduced variety of macronutrients [10].

Sweetened beverages intake was positively associated with risk of prediabetes in other studies [11-14]. The individuals who consumed a median of 6 servings/week had a risk of prediabetes with $46 \%$ greater than individuals that did not consume sodas [15-17]. The impact of soda intake reduction on blood pressure was analyzed in a prospective study and the result was that reduction of soda intake by 1 serving per day determined the reduction of systolic blood pressure by $1.8 \mathrm{mmHg}$ and diastolic blood pressure by $1.1 \mathrm{~mm} \mathrm{Hg}$ [18]. The same study revealed that the reduction of soda intake determined a significant weight loss at 6 months and at 12 months [18].

Sweetened beverages represent the second contributor of free sugar intake in the adult diet [19]. The calories that

Table 2

FREQUENCY OF SWEETENED BEVERAGES CONSUMPTION IN THE YOUNG ADULT POPULATION FROM BIHOR COUNTY AND ITS ASSOCIATION WITH BODY MASS INDEX AND NUMBER OF TIMES BUYING FAST-FOOD PRODUCTS

\begin{tabular}{|c|c|c|c|c|}
\hline \multirow{2}{*}{$\begin{array}{c}\text { No. of soda } \\
\text { servings*/week }\end{array}$} & \multirow{2}{*}{$\begin{array}{c}\mathrm{BMI} \\
\left(\mathrm{kg} / \mathrm{m}^{2}\right)\end{array}$} & $\begin{array}{c}\text { No. of times buying } \\
\text { fast-food products/week }\end{array}$ & \multicolumn{2}{|c|}{ Patients } \\
\cline { 3 - 5 } & $21.8 \pm 4.7$ & $1.5 \pm 1.2$ & No. & $\%$ \\
\hline 0 & $22.3 \pm 5.2$ & $1.8 \pm 1.5$ & 145 & 12.52 \\
\hline $1-2$ & $22.7 \pm 4.8$ & $2.3 \pm 1.3$ & 275 & 23.75 \\
\hline $3-4$ & $23.5 \pm 5.3$ & $2.9 \pm 1.4$ & 347 & 29.97 \\
\hline $5-6$ & $24.4 \pm 4.6$ & $3.2 \pm 1.5$ & 194 & 16.75 \\
\hline $7-8$ & $25.6 \pm 5.8$ & $4.5 \pm 1.9$ & 108 & 9.33 \\
\hline$>8$ & $<0.01$ & $<0.01$ & 89 & 7.69 \\
\hline p-value & & & 1158 & 100 \\
\hline
\end{tabular}

${ }^{*} 1$ serving $=500 \mathrm{~mL}$ sugar sweetened beverage

Table 3

ASSOCIATION BETWEEN THE INTAKE OF SODA, FASTING BLOOD GLUCOSE, SYSTOLIC AND DIASTOLIC BLOOD PRESSURE

\begin{tabular}{|c|c|c|c|c|c|}
\hline $\begin{array}{l}\text { No. of soda } \\
\text { servings/week }\end{array}$ & $\begin{array}{l}\text { Fasting } \\
\text { glycaemia } \\
(\mathrm{mg} / \mathrm{dL})\end{array}$ & $\begin{array}{l}\% \text { of patients with fasting } \\
\text { glycaemia }>100 \mathrm{mg} / \mathrm{dL}^{*}\end{array}$ & $\begin{array}{l}\text { Systolic blood } \\
\text { pressure } \\
\text { (mmHg) }\end{array}$ & $\begin{array}{l}\text { Diastolic blood } \\
\text { pressure } \\
\text { (mmHg) }\end{array}$ & $\begin{array}{l}\% \text { of patients with } \\
\text { SPB }>140 \mathrm{mmHg} \text { or } \\
\text { DBP }>90 \mathrm{mmHg}^{*}\end{array}$ \\
\hline 0 & $81 \pm 4.7$ & 6 & $128 \pm 10.5$ & $81 \pm 5.8$ & 13 \\
\hline $1-2$ & $79 \pm 2.8$ & 8 & $125 \pm 11.8$ & $85 \pm 6.2$ & 14 \\
\hline $3-4$ & $85 \pm 5.2$ & 9 & $131 \pm 12.4$ & $82 \pm 5.2$ & 17 \\
\hline $5-6$ & $90 \pm 5.7$ & 11 & $130 \pm 12.6$ & $86 \pm 6.8$ & 20 \\
\hline $7-8$ & $95 \pm 6.8$ & 15 & $129 \pm 11.4$ & $83 \pm 4.7$ & 21 \\
\hline$>8$ & $99 \pm 7.1$ & 19 & $134 \pm 12.8$ & $89 \pm 7.4$ & 28 \\
\hline p-value & $<0.05$ & $=0.01$ & $=0.05$ & $<0.05$ & $\mathrm{p}=0.01$ \\
\hline
\end{tabular}


they bring in the diet are hidden calories. The mechanism underlying the association between soda intake and weight gain was explored in experimental studies. One study demonstrated that if adults consumed carbohydrates totalizing $1880 \mathrm{~kJ} /$ day as a liquid (soda) for an interval of 4 weeks and then again, after a pause of 4 weeks, for another interval of 4 weeks. they gained weight significantly compared with adults that consumed the same amount of carbohydrates, but as solids [20].

Given the results of this study and many others from literature we believe that is mandatory to introduce interventions for reducing soda consumption in Romania. Educational campaigns to inform the general population about the health risks related to added sugars intakes or even taxing sweetened beverages are viable options.

It was demonstrated that countries who introduced taxing for sweetened beverages buying were able to obtain a decreased consumption of such beverages [21]. Such measures can have a profound impact on the health of young population. Soda consumption represents one of the most important factors for chronic diseases, such as diabetes mellitus and its complications [22,23]. It was demonstrated in a meta-analysis, most powerful level of evidence, that $>1$ drink/week soda consumption increased the risk of type 2 diabetes with $30 \%$ compared with $<1$ drink/month soda consumption [24].

We also have to consider the role of some intensive campaigns of information and education the population on how to feed and what type of food is recommended for a healthy life (or at least for reducing the risk of prevalent diseases in Romania: cardiovascular diseases [25-29], cancer [30-34], etc.); the increased consumption of such products, such as vegetables and fruits (products containing antioxidants and that do not contain harmful fats or processed sugars), would be extremely beneficial to people's health and treatment, with a clear reflection of the decrease in the incidence of various diseases [35-41].

\section{Conclusions}

Our study demonstrates, by finding a statistically significant association between soda intake/week and the other included variables (number of times buying fast-food products/week, body-mass index, fasting glucose, systolic and diastolic blood pressure), the positive relationships between them in the young adult population from north western Romania. Whether these associations are causative or not are debatable, but they exist, must not be ignored and the important aspect is that unhealthy diet patterns can be modified with numerous measures, starting from early education regarding healthy nutrition. We believe that these associations have profound implications for the health burden of this age group and must represent a public health and socioeconomic concern.

\section{References}

1.HRUBY, A., HU, F.B., Pharmacoeconomics, 33, no. 7, 2015, p. 673. 2.GUTHRIE, J.F., MORTON J.F., J. Am. Diet. Assoc., 100, 2000, p. 43. 3.BES-RASTROLLO, M., SANCHEZ-VILLEGAS, A, GOMEZ-GRACIA, E., MARTINEZ, JA., PAJ ARES, R.M., MARTINEZ-GONZALEZ, M.A., Am. J. Clin. Nutr., 83, 2006, p. 362.

4.SCHULZE, M.B., MANSON J.E., LUDWIG, D.S., COLDITZ, G.A., STAMPFER, M.J ., WILLETT, W.C., HU, F.B., JAMA, 292, 2004, p. 927.

5.WINKELMAYER, W.C., STAMPFER, M.J., WILLETT, W.C., CURHAN, G.C., JAMA, 294, 2005, p. 2330.

6.UIVAROSAN D., ABDEL-DAIM M., ENDRES L., PURZA L., IOVAN C., BUNGAU S., FURAU C.G., TIT D.M., Farmacia, 66, no. 5, 2018, p. 826. https://doi.org/10.31925/farmacia.2018.5.12
7.STOICESCU M., CSEPENTO C., MUTIU G., BUNGAU S., Rom. J. Morphol. Embriol., 52, nr. 1 Suppl., 2011, p. 419.

8.MATHIAS, K.C., SLINING, M.M., POPKIN, B.M., Am. J. Prev. Med., 44, no. 4, 2013, p. 351.

9.BASU, S., MCKEE, M., GALEA, G., STUCKLER, D., Am. J. Public. Health, 103, no. 11, 2013, 2071-7.

10.VARTANIAN, L.R., SCHWARTZ, M.B., BROWNELL, K.D., Am. J. Public Health, 97, no. 4, 2007, p. 667.

11.DUMITRU, N., COCOLOS, A., CARAGHEORGHEOPOL, A., DUMITRACHE, C., BRATU, O., NEAGU, T.P., DIACONU, C.C., GHEMIGIAN, A., Rev. Chim. (Bucharest), 69, no. 7, 2018, p.1706.

12.STANESCU, A.M.A., GRAJ DEANU, I.V., IANCU, M.A., PANTEA STOIAN, A., BRATU, O.G., SOCEA, B., SOCEA, L.I., DIACONU, C.C., Rev. Chim. (Bucharest), 69, no. 7, 2018, p. 1668.

13.SOCEA, L.I., VISAN, D.C., BARBUCEANU, S.F., APOSTOL, T.V., BRATU, O.G., SOCEA, B., Rev Chim (Bucharest), 69, no. 4, 2018, p. 795.

14.DIACONU, C., NASTASA, A., ZAKI, A.R., ARSALAN, M. The 2nd International Conference on Interdisciplinary Management of Diabetes Mellitus and its Complications - Diabetes mellitus as cardiovascular disease, INTERDIAB 2016 Proceedings, pp 201-210. Ed. Niculescu.

15.MA, J., J ACQUES, P.F., MEIGS, J B., FOX, C.S., ROGERS, G.T., SMITH, C.E., HRUBY, A., SALTZMAN, E., MCKEOWN, N.M., J. Nutr., 146, no. 12, 2016, p. 2544.

16.PAHONTU, E., SOCEA, L.I., BARBUCEANU, S.F., et al., Rev. Chim. (Bucharest), 69, no. 11, 2018, p. 2959.

17.RADULESCU, D., BALCANGIU STROESCU, A., PRICOP, C., GEAVLETE, B., NEGREI, C., BRATU, O., GINGHINA, O., VACAROIU, I., Rev. Chim. (Bucharest), 68, no. 1, 2017, p. 52.

18.CHEN, L., CABALLERO, B., MITCHELL, D.C., LORIA, C., LIN. P.H., CHAMPAGNE, C.M., ELMER, P.J., ARD, J.D., BATCH, B.C., ANDERSON, C.A., APPEL, L.J ., Circulation, 121, no. 22, 2010, p. 2398.

19.HASHEM, K.M., HE, F.J ., JENNER, K.H., MACGREGOR, G.A., BMJ Open., 6, no.11, 2016; doi:10.1136/bmjopen-2015-010874

20.DIMEGLIO, D.P., MATTES, R.D., Int J Obes Relat Metab Disord., 24, no. 6, 2000, p.794

21.MANIADAKIS, N., KAPAKI, V, DAMIANIDI, L., KOURLABA, G., Clinicoecon. Outcomes Res., 5, 2013, p. 519. doi:10.2147/CEOR.S49659 22.DIACONU, C., DUMITRU, N., FRUNTELATA, A., LACAU, S., BARTOS, D. Acta Cardiologica Sinica, 31,1, 2015, pp. 83-86.

23.CIUHU, A.N., RAHNEA NITA, R.A., POPESCU, M., DUMITRU BADIU, C.D., PANTEA STOIAN, A.M., LUPULIASA, D., GHERGHICEANU, F., DIACONU, C.C., RAHNEA NITA, G. Farmacia, 65, 2, 2017, pp. 173-178. 24.WANG, M., YU, M., FANG, L., HU, R.Y., J Diabetes Investig., 3, no. 6 , 2014, p. 360.

25.DIACONU, C.C., MANEA, M., IANCU, M.A., STANESCU, A.M.A., SOCEA, B., SPINU, D.A., MARCU, D., BRATU, O.G., Rev. Chim. (Bucharest), 69, no. 5, 2018, p. 1071.

26.DIACONU, C.C., DRAGOI, C.M., BRATU, O.G., NEAGU, T.P., PANTEA STOIAN, A., COBELSCHI, P.C., NICOLAE, A.C., IANCU, M.A., HAINAROSIE, R., STANESCU, A.M.A., SOCEA, B., Farmacia, 66, no. 3, 2018, p. 408.

27.DIACONU, C.C., STANESCU, A.M.A., PANTEA STOIAN, A., TINCU, R.C., COBILINSCHI, C., DRAGOMIRESCU, R.I.F., SOCEA, B., SPINU, D.A., MARCU, D., SOCEA, L.I., BRATU, O.G., Rev. Chim. (Bucharest), 69, no. 6, 2018, p. 1367.

28.TIGLIS, M., NEAGU, T. P., ELFARA, M., DIACONU, C. C., BRATU, O.G., VACAROIU, I.A., GRINTESCU, I.M., Rev. Chim. (Bucharest), 69, no. 10, 2018, p. 2877.

29.MANEA, M., MARCU, D., PANTEA STOIAN, A., GAMAN, M. A., GAMAN, A. M., SOCEA, B., NEAGU, T. P., STANESCU, A. M. A., BRATU, O. G., DIACONU, C. C., Rev. Chim. (Bucharest), 69, nr. 11, 2018, p. 4180.

30.STANIMIR, M., CHIUTU, L.C., WESE, S., MILULESCU, A., NEMES, R.N., BRATU, O., Rom. J. Morphol. Embriol., 57, no. 2(suppl.), 2016, p. 849.

31.MARCU, R.D., SPINU, A.D., SOCEA, B., BODEAN, M.O., DIACONU, C.C., VASILESCU, F., NEAGU, T.P., BRATU, O., Rev. Chim. (Bucharest), 69 , no. 4, 2018, p. 823. 
32.BRATU, O., MISCHIANU, D., CONSTANTINOIU, S., Chirurgia, 108, no. 2, 2013, p. 250.

33.BRATU, O., MARCU, R., SOCEA, B., NEAGU, T., DIACONU, C., SCARNECIU, I., TURCU, F., RADAVOI, G., BRATILA, E., BERCEANU, C., SPINU, D., Rev. Chim. (Bucharest), 69, no. 7, 2018, p. 1813.

34.RADAVOI, G.D., PRICOP, C., JINGA, V., MATES, D., RADOI, V.E., JINGA, M., URSU, R.I., BRATU, O.G., MISCHIANU, D.L., IORDACHE, P., Rom. J. Morphol. Embriol., 57, no. 2, 2016, p. 467.

35.ABDEL-DAIM, M.M., ABO-EL-SOOUD, K., ALEYA, L., BUNGAU, S.G., NAJDA, A., SALUJA, R., Oxid. Med. Cell. Longev., 2018, 2018, ID 6276438. 36.ABDEL-DAIM, M.M., ABUSHOUK, A.I., ALKHALF, M.I., TORAIH, E.A., FAWZY, M.S., IJAZ, H., ALEYA, L., BUNGAU, S., Environ. Sci. Pollut. Res. Int., 25, no. 27, 2018, p. 27463. https://doi.org/10.1007/s11356018-2761-0
37.ABDEL-DAIM, M.M., SHAHEEN, H.M., ABUSHOUK, A.I., TORAIH, E.A., FAWZY, M.S., ALANSARI, W.S., ALEYA, L., BUNGAU, S., Environ. Sci. Pollut.Res. Int., 25, no. 24, 2018, p. 23909. https://doi.org/10.1007/ s11356-018-2386-3

38.ABDEL-DAIM, M.M., ZAKHARY, N.I., ALEYA, L., BUNGAU, S.G., BOHARA, R.A., SIDDIQI, N.J., Oxid. Med. Cell. Longev., 2018, 2018, ID 2098123. https://doi:10.1155/2018/2098123

39.APOSTOL, L., BERCA, L., MOSOIU, C., BADEA, M., BUNGAU, S., OPREA, O.B., CIOCA, G., Rev. Chim. (Bucharest), 69, no. 6, 2018, p. 1398.

40.COPOLOVICI, D., BUNGAU, S., BOSCENCU, R, TIT, D. M., COPOLOVICl, L., Rev. Chim (Bucharest), 68, no. 3, 2017, p. 507. 41.FODOR, K., TIT, D.M., PASCA, B., BUSTEA, C., UIVAROSAN, D., ENDRES, L., IOVAN, C., ABDEL-DAIM, M., BUNGAU, S., Oxid. Med. Cell. Longev., 2018, 2018, ID 4147320. https://doi.org/10.1155/2018/ 4147320

$\overline{\text { Manuscript received: } 15.08 .2018}$ 